\title{
Foliar Application of Gibberelic Acid on Growth and Flowering of Gerbera Cultivars
}

\author{
A. F. M. Jamal Uddin*, H. Mehraj, T. Taufique, A. F. Ona and S. Parvin \\ Dept. of Horticulture, Sher-e-Bangla Agricultural University, Dhaka, Bangladesh \\ Corresponding author*: jamal4@yahoo.com
}

\begin{abstract}
An experiment was conducted at Rooftop Garden under 2abotech lab, Department of Horticulture, Sher-e-Bangla Agricultural University, Bangladesh during November 2012 to July 2013 to find out growth and yield performance of potted Gerbera against foliar application of different concentration of Gibberelic acid $\left(G A_{3}\right)$. Three varieties viz. $V_{1}($ red $), V_{2}$ (brick red), $V_{3}$ (pink) and four $G_{3}$ concentrations viz. $G_{0}: 0$ ppm, $G_{1}: 100 \mathrm{ppm}, G_{2}: 150 \mathrm{ppm}$, $G_{3}: 200$ ppm were evaluated in the experiment. Maximum number of flower (22.1), flower bud diameter $(3.6 \mathrm{~cm})$, peduncle length $(29.3 \mathrm{~cm})$, peduncle diameter $(1.9 \mathrm{~mm})$ and flower head diameter $(8.6 \mathrm{~cm})$ were found from $V_{2}$ while $G_{2}$ provided maximum number of flower (24.0), longest peduncle (28.3), maximum peduncle diameter (1.7) but $G_{2}$ and $G_{3}$ both provided maximum flower bud diameter $(3.1 \mathrm{~cm})$ and flower head diameter $(8.1 \mathrm{~cm}) . V_{2} G_{2}$ was found as the best treatment combination.
\end{abstract}

Key words: Gerbera jamesonii, Gibberelic acid and different concentration

\section{Introduction}

Gerbera (Gerbera jamesonii) belonging to the Asteraceae family that ranks among the top ten cut flowers of the world (Parthasarathy and Nagaraju 1999). In Bangladesh, public attraction is gradually increasing particularly in urban areas about gerbera. Genetic diversity that exists in Bangladesh would facilitate selection of gerbera and hormonal balance plays a major role for flower yield like plant growth regulators increases growth, flowering and yield of many ornamental plants. Application of gibberellin may reduce flower and fruit drop due to the suppression of ABA biosynthesis (Steffens 1988). Therefore, an application of exogenous gibberellins might improve flower retention. Thus, keeping in view the potentialities of growth regulators like Gibberelic acid, the study was undertaken to find out the suitable concentration of $\mathrm{GA}_{3}$ for better growth and yield of gerbera.

\section{Materials and Method}

Location and duration of the experiment: This experiment was conducted at Rooftop Garden under 2abotech lab, Department of Horticulture, Sher-e-Bangla Agricultural University, Bangladesh during November 2012 to July 2013.

Experimental design and treatments: Two factorial experiment was laid out in complete randomized design (CRD) with five replications. Three varieties were exerted and these were symbolized by $\mathrm{V}_{1}$ (red), $\mathrm{V}_{2}$ (brick red) and $\mathrm{V}_{3}$ (pink). On the other hand, Gibberelic acid $\left(\mathrm{GA}_{3}\right)$ was sprayed at different concentrations and these were symbolized by $\mathrm{G}_{0}: 0 \mathrm{ppm} ; \mathrm{G}_{1}: 100 \mathrm{ppm} ; \mathrm{G}_{2}: 150 \mathrm{ppm}$ and $\mathrm{G}_{3}: 200 \mathrm{ppm}$. 
Genetic materials and fertilization: Same aged seedlings were collected from local nursery, Dhaka. Soil and cow-dung (1:1) were mixed and pots were filled 7 days before transplanting. Recommended chemical fertilizers (NPK as 5, 10 and $5 \mathrm{~g}$ respectively in each pot) were mixed with the soil.

Data collection: Data were collected on number of leaves, leaf length, leaf breadth, days to first flower bud initiation, days to first flowering, number of flower, flower bud diameter, peduncle length, peduncle diameter and flower head diameter from each pot within the period. Number of leaves, leaf length and leaf breadth were measured at every 30 days interval from 30 DAT and continued up to 210 DAT. Peduncle diameter were measured by using Digital Caliper-515 (DC-515).

Statistical analysis: All parameters were statistically analyzed by using MSTAT-C program. Mean for all the treatments was calculated, analysis of variance for each of the characters was performed by Ftest and difference between treatments was evaluated by Least Significant Difference (LSD) at 5\% level of significance (Gomez and Gomez 1984).

\section{Results and Discussion}

Number of leaves: Maximum number of leaves was found from $\mathrm{V}_{3}(37.4)$ while minimum from $\mathrm{V}_{1}$ (35.4) at 210 days after transplanting (Figure 1a). On the other hand, $\mathrm{G}_{2}$ (spraying of $150 \mathrm{ppm} \mathrm{GA}_{3}$ ) provided maximum number (38.5) of leaves which was statistically similar with $\mathrm{G}_{3}$ (38.3) whereas minimum from $\mathrm{G}_{0}$ (34.2) at 210 days after transplanting (Fig. 1b). Application of Gibberelic acid increases the leaf number of strawberry (Jamal Uddin et al., 2012). Gibberellic acid resulted in cell division and cell elongation can cause in enhanced vegetative growth. In combination between variety and $\mathrm{GA}_{3}$ spraying, $\mathrm{V}_{3} \mathrm{G}_{2}$ (38.5) provided maximum number of leaves whereas minimum (35.3) from $\mathrm{V}_{1} \mathrm{G}_{1}, \mathrm{~V}_{1} \mathrm{G}_{2}$ and $\mathrm{V}_{2} \mathrm{G}_{3}$ at 210 days after transplanting (Table 3).

Leaf length: Leaf length was varied significantly among the gerbera varieties, $\mathrm{GA}_{3}$ spraying and their combination. Longest leaf was found from $V_{2}(27.8 \mathrm{~cm})$ while shortest from $\mathrm{V}_{1}(23.0 \mathrm{~cm})$ (Figure 1c). $\mathrm{G}_{2}(27.1 \mathrm{~cm})$ provided longest leaf whereas shortest from $\mathrm{G}_{0}(21.0 \mathrm{~cm})$ (Figure 1d). Length of leaf increased by using $\mathrm{GA}_{3}$ (Cardoso et al. 2012). In combination between variety and $\mathrm{GA}_{3}$ spraying, $\mathrm{V}_{2} \mathrm{G}_{2}(30.9 \mathrm{~cm})$ provided longest leaf whereas minimum from $\mathrm{V}_{1} \mathrm{G}_{0}(35.3)$ at 210 days after transplanting (Table 3).

Leaf width: The widest leaf was observed from $V_{2}(12.6 \mathrm{~cm})$ while narrowest from $V_{3}(11.9 \mathrm{~cm})$ at 210 days after transplanting (Figure 1e). Among the different concentration of $\mathrm{GA}_{3}$ spraying widest leaf was found from $\mathrm{G}_{2}(12.9 \mathrm{~cm})$ while narrowest from $\mathrm{G}_{0}(11.8 \mathrm{~cm})$ at 210 days after transplanting (Fig. 1f). On the other hand $\mathrm{V}_{2} \mathrm{G}_{2}$ provided widest $(13.8 \mathrm{~cm})$ leaf whereas narrowest from $\mathrm{V}_{3} \mathrm{G}_{3}(11.2)$ at 210 days after transplanting (Table 3 ).

Days to flower bud initiation: Days to flower bud initiation varied significantly among the variety, $\mathrm{GA}_{3}$ spraying and their combination. Early flower bud initiation occurred in $\mathrm{V}_{2}$ (68.2 days) while $\mathrm{V}_{1}$ (81.2 days) showed the late flower bud initiation which was statistically similar to the $\mathrm{V}_{3}$ (80.7 days) (Table 1). $\mathrm{G}_{2}$ treatment (72.6 days) provided early flower bud initiation which was statistically similar with the $\mathrm{G}_{3}$ (73.0 days) and $\mathrm{G}_{1}$ (74.3 days) but late flower bud initiation from $\mathrm{G}_{0}$ ( 86.9 days) (Table 2 ). From the current study it was observed that application of $\mathrm{GA}_{3}$ influenced significantly for the early flower bud initiation but not significantly affected by their concentration. Inflorescences were emerged earlier than control, when those plants were treated with $\mathrm{GA}_{3}$ (Matsumoto 2006). In combination of variety and $\mathrm{GA}_{3}$ spraying, $\mathrm{V}_{2} \mathrm{G}_{2}$ provided early flower bud initiation (61.0 days) while $\mathrm{V}_{1} \mathrm{G}_{0}(109.0$ days) was the late flower bud initiating combination (Table 3 ).

Days to flowering: Days to flowering varied significantly among the variety, $\mathrm{GA}_{3}$ spraying and their combination. Early flowering occurred in $\mathrm{V}_{2}$ (80.9 days) while $\mathrm{V}_{1}$ (93.5 days) showed the late 
flowering which was statistically similar to the $\mathrm{V}_{3}$ (92.6 days) (Table 1). $\mathrm{G}_{3}$ treatment (85.3 days) provided early flowering which was statistically similar with the $\mathrm{G}_{2}$ (85.5 days) and $\mathrm{G}_{1}$ (86.5 days) but late flower bud initiation from $\mathrm{G}_{0}$ (98.7 days) (Table 2). From the current study it was observed that application of $\mathrm{GA}_{3}$ influenced significantly for early flowering but not significantly affected by their concentration. Jamal Uddin et al. (2012) found that $\mathrm{GA}_{3}$ application caused early flowering in strawberry. Application of $\mathrm{GA}_{3}$ induced early flowering (Hernandez 1997 and Awan et al. 1999). $\mathrm{GA}_{3}$ seemed to decrease ABA concentration and to boot t-ZR (trans-Zeatin Riboside) up in leaf that might be related to flower buds initiation and early flowering (Phengphachanh et al. 2012). In combination of variety and $\mathrm{GA}_{3}$ spraying, $\mathrm{V}_{2} \mathrm{G}_{2}$ provided early flowering (74.8 days) while $\mathrm{V}_{1} \mathrm{G}_{0}$ (121.1 days) was the late flowering combination (Table 3 ).

Number of flower: No of flower varied significantly among the varieties, different concentration of $\mathrm{GA}_{3}$ and their combinations. $\mathrm{V}_{2}$ (22.1) provided maximum number of flower/plant which was statistically similar with $\mathrm{V}_{3}$ (22.0) whereas minimum from $\mathrm{V}_{1}$ (20.0) (Table 1). Gerbera cultivar produced 20-35 flower stick per plant annually on an average (Li Zhang et al. 2008, Singh and Mandhar 2004) which have strongly support the findings of the current study. For the foliar application of different concentration of $\mathrm{GA}_{3}, \mathrm{G}_{2}$ (24.0) provided maximum number of flower while minimum from $\mathrm{G}_{0}$ (18.6) (Table 2). Foliar application of GA3 increases number of flower in strawberry (Jamal Uddin et al. 2012). Flower abscissions are usually due to high level of ethylene in the flower (Malik et al. 2003, Beno-Moualem et al. 2004) and the lower concentration of auxin and gibberellin (Aneja and Gianfagna 1999, Malik and Singh 2006). In combination of variety with different concentration of $\mathrm{GA}_{3}$ spraying, $\mathrm{V}_{2} \mathrm{G}_{2}$ (27.8) showed the tendency for more flowering while minimum from $\mathrm{V}_{2} \mathrm{G}_{0}(16.8)$ (Table 4).

Flower bud diameter: Flower bud diameter varied significantly among the varieties and the combination between variety and foliar spraying of $\mathrm{GA}_{3}$. In case of variety, maximum flower bud diameter was observed from $V_{2}(8.6 \mathrm{~cm})$ whereas minimum from $V_{1}$ and $V_{3}(7.7 \mathrm{~cm})$ (Table 1$)$. Significant variation did not find among the different concentration of foliar spraying of $\mathrm{GA}_{3}$. However, maximum flower bud diameter was observed from $\mathrm{G}_{2}(8.1 \mathrm{~cm})$ and $\mathrm{G}_{3}(8.1 \mathrm{~cm})$ while minimum from $\mathrm{G}_{0}(7.9 \mathrm{~cm})$ (Table 2). In combination among variety and different concentration of $\mathrm{GA}_{3}$ spraying, maximum flower bud diameter was found from $\mathrm{V}_{2} \mathrm{G}_{2}(9.2 \mathrm{~cm})$ while minimum from $\mathrm{V}_{1} \mathrm{G}_{0}(2.4)$ and $\mathrm{V}_{1} \mathrm{G}_{2}(2.4 \mathrm{~cm})$ (Table 4).

Peduncle length: Peduncle length of flower varied significantly among the varieties, different concentration of $\mathrm{GA}_{3}$ spraying and their combinations. Longest peduncle was found from $\mathrm{V}_{2}(29.3$ $\mathrm{cm}), \mathrm{G}_{2}(28.3 \mathrm{~cm})$ and $\mathrm{V}_{2} \mathrm{G}_{2}(33.3 \mathrm{~cm})$ (Table 1,2 and 3 respectively) while shortest from $\mathrm{V}_{3}(24.6$ $\mathrm{cm}), \mathrm{G}_{0}(23.4 \mathrm{~cm})$ and $\mathrm{V}_{1} \mathrm{G}_{0}(21.7 \mathrm{~cm})$ (Table 1, 2 and 3 respectively). Mehraj et al. (2013) found that peduncle of brick red gerbera ranges from $26.7 \mathrm{~cm}$ to $36.1 \mathrm{~cm}$ that supports the findings of the current study.

Peduncle diameter: Peduncle diameter of flower varied significantly among the varieties, different concentration of $\mathrm{GA}_{3}$ spraying and their combinations. Maximum peduncle diameter was found from $\mathrm{V}_{2}(1.9 \mathrm{~mm}), \mathrm{G}_{2}(1.7 \mathrm{~mm})$ and $\mathrm{V}_{2} \mathrm{G}_{2}(2.2 \mathrm{~mm})$ (Table 1,2 and 3 respectively) while minimum from $\mathrm{V}_{3}$ $(1.4 \mathrm{~mm})$ and $\mathrm{G}_{0}(1.5 \mathrm{~mm})$ (Table 1 , and 2 respectively). On the other hand, minimum $(1.4 \mathrm{~mm})$ was observed from $\mathrm{V}_{1} \mathrm{G}_{0}, \mathrm{~V}_{1} \mathrm{G}_{1}, \mathrm{~V}_{3} \mathrm{G}_{0}, \mathrm{~V}_{3} \mathrm{G}_{1}$ and $\mathrm{V}_{3} \mathrm{G}_{3}$ (Table 4).

Flower head diameter: Flower head diameter varied significantly among the varieties and the combination between variety and foliar spraying of $\mathrm{GA}_{3}$. In case of variety, maximum flower head diameter was observed from $V_{2}(8.6 \mathrm{~cm})$ whereas minimum from $V_{1}$ and $V_{3}(7.7 \mathrm{~cm})$ (Table 1$)$. Significant variation was not found among the different concentration of foliar spraying of $\mathrm{GA}_{3}$. However, maximum flower bud diameter was observed from $\mathrm{G}_{2}(8.1 \mathrm{~cm})$ and $\mathrm{G}_{3}(8.1 \mathrm{~cm})$ while minimum from $\mathrm{G}_{0}(7.9 \mathrm{~cm})$ and $\mathrm{G}_{1}(8.0 \mathrm{~cm})$ (Table 2). In combination among variety and different 
concentration of $\mathrm{GA}_{3}$ spraying, maximum flower bud diameter was found from $\mathrm{V}_{2} \mathrm{G}_{2}(9.2 \mathrm{~cm})$ while minimum from $\mathrm{V}_{1} \mathrm{G}_{0}$ (7.4) (Table 4).
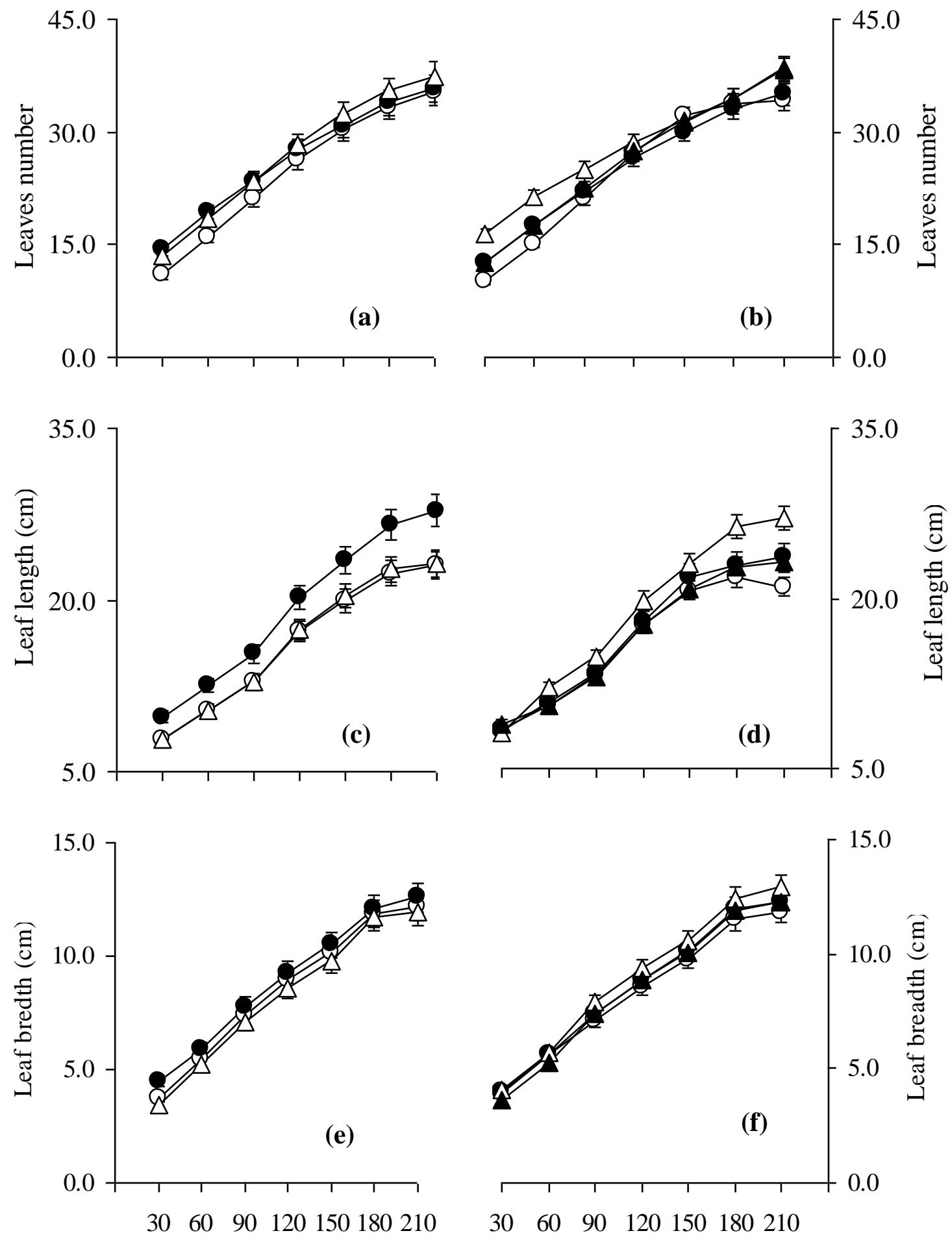

Days after transplanting (DAT)

Days after transplanting (DAT)
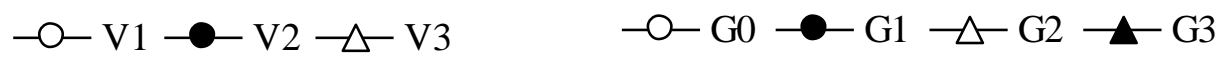

Figure 1. Performance of leaf number (a \& b ); leaf length (c \& d); leaf breadth (e \& f) on gerbera variety (a, c \& e) and $\mathrm{GA}_{3}$ concentration $(b, d \& f)$ 
Table 1. Performance of gerbera variety to different attributes ${ }^{x}$

\begin{tabular}{|c|c|c|c|c|c|c|c|c|c|c|c|c|c|c|}
\hline \multirow{2}{*}{$\begin{array}{l}\text { Variety } \\
V_{1}\end{array}$} & \multicolumn{2}{|c|}{$\begin{array}{l}\text { Days to first } \\
\text { flower bud } \\
\text { initiation }\end{array}$} & \multicolumn{2}{|c|}{$\begin{array}{l}\text { Days to first } \\
\text { flowering }\end{array}$} & \multicolumn{2}{|c|}{$\begin{array}{l}\text { No of } \\
\text { flower } \\
\text { /plant }\end{array}$} & \multicolumn{2}{|c|}{$\begin{array}{l}\text { Flower } \\
\text { bud } \\
\text { diameter } \\
(\mathrm{cm})\end{array}$} & \multicolumn{2}{|c|}{$\begin{array}{l}\text { Peduncle } \\
\text { length } \\
(\mathrm{cm})\end{array}$} & \multicolumn{2}{|c|}{$\begin{array}{l}\text { Peduncle } \\
\text { diameter } \\
(\mathrm{cm})\end{array}$} & \multicolumn{2}{|c|}{$\begin{array}{c}\text { Flower } \\
\text { head } \\
\text { diameter } \\
(\mathrm{cm})\end{array}$} \\
\hline & 81.2 & $\mathrm{a}$ & 93.52 & $\mathrm{a}$ & 20.0 & b & 2.7 & b & 25.7 & $\mathrm{~b}$ & 1.5 & $\mathrm{~b}$ & 7.7 & $\mathrm{~b}$ \\
\hline $\mathrm{V}_{2}$ & 68.2 & $\mathrm{~b}$ & 80.93 & b & 22.1 & $\mathrm{a}$ & 3.6 & $\mathrm{a}$ & 29.3 & $\mathrm{a}$ & 1.9 & $\mathrm{a}$ & 8.6 & $\mathrm{a}$ \\
\hline $\mathrm{V}_{3}$ & 80.7 & $\mathrm{a}$ & 92.59 & $\mathrm{a}$ & 22.0 & $\mathrm{a}$ & 2.7 & $\mathrm{~b}$ & 24.6 & $\mathrm{c}$ & 1.4 & $\mathrm{~b}$ & 7.7 & $\mathrm{~b}$ \\
\hline LSD0.05 & $\begin{array}{r}6.0 \\
10.9\end{array}$ & & 6.0 & & $\begin{array}{r}0.7 \\
114\end{array}$ & & $\begin{array}{r}0.2 \\
111\end{array}$ & & $\begin{array}{l}0.9 \\
46\end{array}$ & & $\begin{array}{c}0.1 \\
104\end{array}$ & & $\begin{array}{r}0.2 \\
112\end{array}$ & \\
\hline
\end{tabular}
level of significance

Table 2. Performance of gerbera variety against different concentration of $\mathrm{GA}_{3}$ spraying to different attributes $^{x}$

\begin{tabular}{|c|c|c|c|c|c|c|c|}
\hline $\begin{array}{c}\mathrm{GA}_{3} \\
\text { Concentrations }\end{array}$ & $\begin{array}{l}\text { Days to first } \\
\text { flower bud } \\
\text { initiation }\end{array}$ & $\begin{array}{l}\text { Days to first } \\
\text { flowering }\end{array}$ & $\begin{array}{l}\text { No of } \\
\text { flower } \\
\text { /plant }\end{array}$ & $\begin{array}{c}\text { Flower } \\
\text { bud } \\
\text { diameter } \\
(\mathrm{cm})\end{array}$ & $\begin{array}{l}\text { Peduncle } \\
\text { length } \\
\text { (cm) }\end{array}$ & $\begin{array}{l}\text { Peduncle } \\
\text { diameter } \\
(\mathrm{cm})\end{array}$ & $\begin{array}{c}\text { Flower } \\
\text { head } \\
\text { diameter } \\
(\mathrm{cm})\end{array}$ \\
\hline $\mathrm{G}_{0}$ & $86.9 \mathrm{a}$ & $98.7 \quad \mathrm{a}$ & $18.6 \mathrm{~d}$ & $2.9 \quad \mathrm{a}$ & $23.4 \quad c$ & $1.5 \mathrm{~b}$ & $7.9 \mathrm{a}$ \\
\hline $\mathrm{G}_{1}$ & $74.3 \mathrm{~b}$ & $86.5 \mathrm{~b}$ & $20.6 \mathrm{c}$ & $2.9 \mathrm{a}$ & $27.0 \quad b$ & $1.6 \mathrm{ab}$ & $8.0 \quad \mathrm{a}$ \\
\hline $\mathrm{G}_{2}$ & $72.6 \quad b$ & $85.5 \quad b$ & $24.0 \quad \mathrm{a}$ & $3.1 \mathrm{a}$ & $28.3 \quad$ a & $1.7 \mathrm{a}$ & $8.1 \quad \mathrm{a}$ \\
\hline $\mathrm{G}_{3}$ & $73.0 \quad b$ & $85.3 \quad b$ & $22.3 \mathrm{~b}$ & $3.1 \quad \mathrm{a}$ & $27.4 \mathrm{ab}$ & $1.6 \mathrm{ab}$ & $8.1 \quad \mathrm{a}$ \\
\hline LSD0.05 & 6.9 & 6.9 & 0.8 & 0.3 & 1.0 & 0.1 & 0.3 \\
\hline CV\% & 10.9 & 9.4 & 11.4 & 11.1 & 4.6 & 10.4 & 11.2 \\
\hline
\end{tabular}

Table 3. Performances of gerbera variety in combination with different concentration of GA3 spraying to different attributes ${ }^{x}$

\begin{tabular}{|c|c|c|c|c|c|c|c|c|c|c|}
\hline \multirow{2}{*}{ Combinations } & \multicolumn{6}{|c|}{$\begin{array}{l}\text { Leaf At } 210 \text { Days after } \\
\text { transplanting (DAT) }\end{array}$} & \multicolumn{4}{|c|}{ Days to first } \\
\hline & \multicolumn{2}{|c|}{ Number } & \multicolumn{2}{|c|}{$\begin{array}{l}\text { Length } \\
(\mathrm{cm})\end{array}$} & \multicolumn{2}{|c|}{$\begin{array}{l}\text { Breadth } \\
(\mathrm{mm})\end{array}$} & \multicolumn{2}{|c|}{$\begin{array}{c}\text { Bud } \\
\text { initiation }\end{array}$} & \multicolumn{2}{|c|}{ Flowering } \\
\hline $\mathrm{V}_{1} \mathrm{G}_{0}$ & 35.5 & $\mathrm{e}$ & 21.8 & $\mathrm{k}$ & 12.1 & $\mathrm{f}$ & 109.0 & $\mathrm{a}$ & 121.1 & $\mathrm{a}$ \\
\hline $\mathrm{V}_{1} \mathrm{G}_{1}$ & 35.3 & $\mathrm{f}$ & 22.7 & $\mathrm{~h}$ & 11.9 & $\mathrm{~h}$ & 73.0 & bcde & 84.9 & bcd \\
\hline $\mathrm{V}_{1} \mathrm{G}_{2}$ & 35.3 & $\mathrm{f}$ & 24.2 & $f$ & 12.9 & $\mathrm{c}$ & 72.8 & bcde & 85.7 & bed \\
\hline $\mathrm{V}_{1} \mathrm{G}_{3}$ & 35.5 & $\mathrm{e}$ & 23.4 & g & 12.4 & e & 70.0 & cde & 82.4 & $\mathrm{~cd}$ \\
\hline $\mathrm{V}_{2} \mathrm{G}_{0}$ & 37.3 & $\mathrm{c}$ & 27.2 & $\mathrm{c}$ & 11.4 & $\mathrm{i}$ & 73.5 & bcd & 84.9 & bcd \\
\hline $\mathrm{V}_{2} \mathrm{G}_{1}$ & 34.5 & $\mathrm{~g}$ & 27.8 & $\mathrm{~b}$ & 12.4 & e & 70.5 & cde & 82.9 & $\mathrm{~cd}$ \\
\hline $\mathrm{V}_{2} \mathrm{G}_{2}$ & 36.3 & $\mathrm{~d}$ & 30.9 & a & 13.8 & $\mathrm{a}$ & 61.0 & $\mathrm{e}$ & 74.8 & d \\
\hline $\mathrm{V}_{2} \mathrm{G}_{3}$ & 35.5 & e & 25.3 & $\mathrm{e}$ & 13.4 & $\mathrm{~b}$ & 67.8 & de & 81.1 & $\mathrm{~cd}$ \\
\hline $\mathrm{V}_{3} \mathrm{G}_{0}$ & 35.3 & $\mathrm{f}$ & 22.2 & $\mathrm{j}$ & 11.9 & $\mathrm{~h}$ & 78.3 & bcd & 90.2 & $\mathrm{bc}$ \\
\hline $\mathrm{V}_{3} \mathrm{G}_{1}$ & 38.0 & $\mathrm{~b}$ & 22.2 & $\mathrm{j}$ & 12.5 & d & 79.3 & bcd & 91.7 & bc \\
\hline $\mathrm{V}_{3} \mathrm{G}_{2}$ & 38.5 & $\mathrm{a}$ & 26.1 & d & 12.0 & g & 84.0 & b & 96.0 & b \\
\hline $\mathrm{V}_{3} \mathrm{G}_{3}$ & 38.0 & $\mathrm{~b}$ & 22.3 & $\mathrm{i}$ & 11.2 & $\mathrm{j}$ & 81.3 & $\mathrm{bc}$ & 92.4 & bc \\
\hline LSD0.05 & 0.1 & & 0.1 & & 0.2 & & 12.0 & & 12.0 & \\
\hline CV\% & 7.3 & & 4.8 & & 1.9 & & 10.9 & & 9.4 & \\
\hline
\end{tabular}


Table 4. Permormance of gerbera variety in combination with different concentration of GA3 spraying to different attributes ${ }^{x}$

\begin{tabular}{|c|c|c|c|c|c|c|c|c|c|c|}
\hline \multirow{3}{*}{$\begin{array}{l}\text { Combinations } \\
\mathrm{V}_{1} \mathrm{G}_{0}\end{array}$} & \multicolumn{6}{|c|}{ Flower } & \multicolumn{4}{|c|}{ Peduncle } \\
\hline & \multicolumn{2}{|c|}{ Number } & \multicolumn{2}{|c|}{$\begin{array}{c}\text { Bud } \\
\text { diameter } \\
(\mathrm{cm})\end{array}$} & \multicolumn{2}{|c|}{$\begin{array}{l}\text { Head } \\
\text { diameter } \\
(\mathrm{cm})\end{array}$} & \multicolumn{2}{|c|}{$\begin{array}{l}\text { Length } \\
(\mathrm{cm})\end{array}$} & \multicolumn{2}{|c|}{$\begin{array}{l}\text { Diameter } \\
(\mathrm{mm})\end{array}$} \\
\hline & 18.8 & $\mathrm{~g}$ & 2.4 & $\mathrm{e}$ & 7.4 & $\mathrm{~d}$ & 21.7 & $\mathrm{~g}$ & 1.4 & $\mathrm{c}$ \\
\hline $\mathrm{V}_{1} \mathrm{G}_{1}$ & 20.8 & ef & 3.1 & $\mathrm{bc}$ & 7.7 & $\mathrm{~cd}$ & 26.8 & cde & 1.4 & $\mathrm{c}$ \\
\hline $\mathrm{V}_{1} \mathrm{G}_{2}$ & 21.0 & de & 2.4 & $\mathrm{e}$ & 8.1 & $\mathrm{bc}$ & 27.5 & $\mathrm{~cd}$ & 1.6 & $\mathrm{c}$ \\
\hline $\mathrm{V}_{1} \mathrm{G}_{3}$ & 19.5 & fg & 2.7 & cde & 7.7 & $\mathrm{~cd}$ & 26.7 & cde & 1.5 & $\mathrm{c}$ \\
\hline $\mathrm{V}_{2} \mathrm{G}_{0}$ & 16.8 & $\mathrm{~h}$ & 3.5 & b & 8.5 & b & 26.0 & de & 1.9 & $\mathrm{~b}$ \\
\hline $\mathrm{V}_{2} \mathrm{G}_{1}$ & 18.8 & $\mathrm{~g}$ & 3.1 & $\mathrm{bc}$ & 8.1 & $\mathrm{bc}$ & 28.1 & $\mathrm{bc}$ & 1.6 & $\mathrm{c}$ \\
\hline $\mathrm{V}_{2} \mathrm{G}_{2}$ & 27.8 & $\mathrm{a}$ & 4.1 & $\mathrm{a}$ & 9.2 & $\mathrm{a}$ & 33.3 & $\mathrm{a}$ & 2.2 & $\mathrm{a}$ \\
\hline $\mathrm{V}_{2} \mathrm{G}_{3}$ & 25.3 & b & 3.6 & $a b$ & 8.6 & b & 29.7 & $\mathrm{~b}$ & 1.9 & $\mathrm{~b}$ \\
\hline $\mathrm{V}_{3} \mathrm{G}_{0}$ & 20.3 & ef & 2.8 & cde & 7.8 & $\mathrm{~cd}$ & 22.4 & $\mathrm{c}$ & 1.4 & $\mathrm{c}$ \\
\hline $\mathrm{V}_{3} \mathrm{G}_{1}$ & 22.3 & $\mathrm{~cd}$ & 2.5 & de & 7.5 & $\mathrm{~d}$ & 26.0 & de & 1.4 & $\mathrm{c}$ \\
\hline $\mathrm{V}_{3} \mathrm{G}_{2}$ & 23.3 & c & 2.8 & cde & 7.8 & $\mathrm{~cd}$ & 24.2 & f & 1.5 & $\mathrm{c}$ \\
\hline $\mathrm{V}_{3} \mathrm{G}_{3}$ & 22.3 & $\mathrm{~cd}$ & 2.9 & $\mathrm{~cd}$ & 7.9 & $\mathrm{~cd}$ & 25.6 & ef & 1.4 & $\mathrm{c}$ \\
\hline $\begin{array}{l}\text { LSD0.0 } \\
\end{array}$ & 1.4 & & 0.5 & & 0.5 & & 1.8 & & 0.2 & \\
\hline CV\% & 11.4 & & 11.1 & & 11.2 & & 4.6 & & 10.4 & \\
\hline
\end{tabular}

\section{Conclusion}

It was revealed from the study that brick red variety was the best among three varieties used in the experiment; and foliar application of $150 \mathrm{ppm}$ Gibberelic acid increases the number of flower in addition with peduncle length diameter and flower head diameter. It can be concluded that foliar application of $150 \mathrm{ppm}$ Gibberelic acid on brick red variety provide the best result in terms of yield and flowering of Gerbera.

\section{References}

Aneja, M. and Gianfagna, T. (1999). The role of abscission and ethylene in the abscission and drop of cocoa flower. Plant Growth Regul. 27: 149-155.

Awan, I. U., Baloch, M. S., Sadozai, N. S. and Sulemani, M. Z. (1999). Stimulatory effect of $\mathrm{GA}_{3}$ and IAA on ripening process, kernel development and quality of rice. Pak. J. Bio. Sci. 2: 410-412.

Cardoso, J. C., Ono, E. O. and Rodrigues, J. D. (2012). Gibberellic acid in vegetative and reproductive development of Phalaenopsis orchid hybrid genus. Horticultura Brasileira 30: 71-74.

Gomez, K. A. and Gomez A. A. (1984). Statistical Procedures for Agricultural Research. $2^{\text {nd }}$ edn. John Wiley and Sons. New York.: 680.

Hernandez. (1997). Morphogenesis in sunflower (Helianthus annuus L.) as affected by exogenous application of plant growth regulators. Agric. Scientia. 13: 3-11.

Jamal Uddin, A. F. M., Hossan, M. J., Islam, M. S., Ahsan, K. and Mehraj, H. (2012). Strawberry Growth and Yield Responses to Gibberellic Acid Concentrations. J. of Expt. Biosci. 3(2): 5156.

Li-Zhang, C., Liu, J. Z., Wu, L. J. Y., Cao, H. and Li, H. (2008). A new cut flower gerbera cultivar 'Liangfen' with resistance to Phytophthora cryptogea. Acta Hort. 35(3): 466. 
Malik, A. U. and Singh, Z. (2006). Improved fruit retention, yield and fruit quality in mango with exogenous application of polyamines. Sci. Hortic. 110: 167-174.

Malik, A. U., Agrez, V. and Singh, Z. (2003). Fruitlet abscission of mango in relation to ethylene. $J$ Hortic. Sci. Biotechnol. 78: 458-462.

Matsumoto, T. K. (2006). Gibberellic acid and Benzylladenine promote early flowering and vegetative growth of Miltoniopsis orchid hybrids. Hort. Sci. 41: 131-135.

Mehraj, H., Taufique, T., Ona, A. F., Roni, M. Z. K. and Jamal Uddin, A. F. M. (2013). Effect of spraying frequency of gibberellic acid on growth and flowering in gerbera. J. Expt. Biosci. 4(2): 7-10.

Parthasarathy, V. A. and Nagaraju, V. (1999). In vitro propagation in Gerbera jamesonii Bolus. Indian J. of Horticulture 56: 82-85.

Phengphachanh, B., Naphrom, D., Bundithya, W. and Potapohn, N. (2012). Effects of Day length and Gibberellic Acid (GA3) on Flowering and Endogenous Hormone Levels in Rhynchostylis gigantea (Lindl.) Ridl. J. of Agril. Sci. 4(4): 217-222.

Singh, K. P. and Mandhar, S. C. (2004). Performance of gerbera (Gerbera jamesonii), cultivars under fan and pad cooled greenhouse environments. J. Appl. Hort. 4(1): 56-59.

Steffens, G. L. (1988). Gibberellin biosynthesis inhibitors comparing growth retarding effectiveness on apple. Plant Growtth Regul. 7: 27-36.

\section{Citation for this article (APA Style)}

Jamal Uddin, A. F. M., Mehraj, H., Taufique, T., Ona, A. F. \& Parvin, S. (2014). Foliar Application of Gibberelic Acid on Growth and Flowering of Gerbera Cultivars. Journal of Bioscience and Agriculture Research, 02(01), 51-58.

Retrieved November 14, 2014, from http://www.journalbinet.com/current-issue-jbar-1.html. 